\title{
THE GIS MODELING OF THE TERRAIN FAVORABILITY FOR THE PLACEMENT OF CONSTRUCTIONS IN THE AREAS WITH HYDRO-GEOMORPHOLOGICAL RISK
}

DOI: https://doi.org/10.18509/AGB.2019.03

UDC: 004:528.8/.9]:551.311.2:624.13

\author{
Vasile Bogdan Ghindaoanu, Elena Hutanu, Andrei Urzica \\ Alexandru Ioan Cuza University of Iasi, Faculty of Geography and Geology, \\ Department of Geography, Romania
}

corresponding author: vasile_bogdan.ghindaoanu@yahoo.com

submitted: 05.03 .2018
accepted: 01.06 .2018
published: 01.11 .2018

\begin{abstract}
The placement of constructions in the areas subjected to hydrogeomorphological hazards is a global issue. Problems of hydrogeomorphological risk are registered between the communes of Broșteni and Poiana Teiului. For the analysis of the construction's favorability, we analyzed the following elements: the elevation model of the terrain, the declivity, the usage of the land, the depth of the terrain's fragmentation, and the terrain's vulnerability to floods. The map of the slopes, together with the guide for the application of the construction's placement regulations, highlight the morphological favorability for the placement of constructions. The map of land usage was realized based on the orthophoto map realized in 2012, and on the topographic and cadastral plans (1981) on a 1:5000 scale. The distribution of the categories of usage in the territory represents a significant parameter for the evaluation of the susceptibility of the manifestation of hydrogeomorphological processes with a negative impact. The map of flooding risk was realized in order to highlight the destructive potential of the floodplains, with a probability of $1 \%$ and $5 \%$. The depth of the terrain fragmentation reflects the altitudinal steps from the level of the minor river bed towards the meadow section and towards the slope so that the favorability of the construction will be highlighted (according to the legal stipulations). The placement of constructions in the proximity of the minor river bed can be observed. This is due to the existence of large slopes on the largest part of the valley sector. Unfortunately, the lower meadows of the terraces do not represent the most favorable placement location of houses, because they are subject to floods, especially to the associated ones (rising levels of water and thaw formation).
\end{abstract}

Keywords: floods, major river bed, reservoir, thaw formation, villages

\section{INTRODUCTION}

Hydric risks in large river basins are some of the most frequent threats associated with natural hazards $[1,2]$. In the first place, for the optimal management of these situations, it is required to realize the detailed cartographic materials, which will highlight the areas that are most vulnerable to the risk phenomena [3-5]. These thematic maps and detailed plans facilitate the development of specific strategies and measures that can lower the impact of natural events [6].

The spacing of the territories affected by the overflowing waters during floods is highly important in the plans of regional and local improvement of the territory. The risk of flooding is a subject that is extremely well studied at both a national [7-19] and international [20-29] level because the material damage and loss of human life caused by these events are very high [30, 31].

This study aims to delimitate the areas favorable to construction from the areas that are unfavorable, in order to be able to highlight whether the current placement of the construction is in the area with a hydro-geomorphologic risk potential, and to intervene in the future with measures that are in accordance with the safety of the population. Throughout the study, we aim to discover the graphic representation of the land use in relation to the slope of the land and the floodplains with different probabilities $(0.1 \%, 1 \%, 5 \%)$. 


\section{STUDY AREA}

The Bistrita River springs from the Rodnei Mountains, at an altitude of 1850 meters, and it is located in North-eastern Romania, in the Eastern Carpathians [32]. The area proposed for study is located at roughly the middle of the distance between the spring of the river and its spill into the Siret River, between the town of Brosteni (47 ${ }^{\circ} 14^{\prime} 39^{\prime \prime} \mathrm{N}$ lat. - ${ }^{\circ} 41^{\prime} 53^{\prime \prime}$ E long.) and Poiana Teiului (476ㄴ $42^{\prime \prime} \mathrm{N}$ lat. - $25^{\circ} 55^{\prime} 26^{\prime \prime}$ E long.), on the territory of the Neamt and Suceava Counties. Located on the north-eastern side of the country,
Bistriţa is in a fully temperate area which is dominated by a temperate continental climate with weak oceanic influences. Thus, the relief of the region has evolved within the fluvial modeling system. The Carpathian landscape crossed by the Bistrița River is made up of medium mountains. The general character is given by the orientation of the peaks in accordance with the great structural lines on the NW - SE direction. The landscape fragmentation is accentuated, being constant at an altitude of approximately 700-900 meters (Fig. 1).

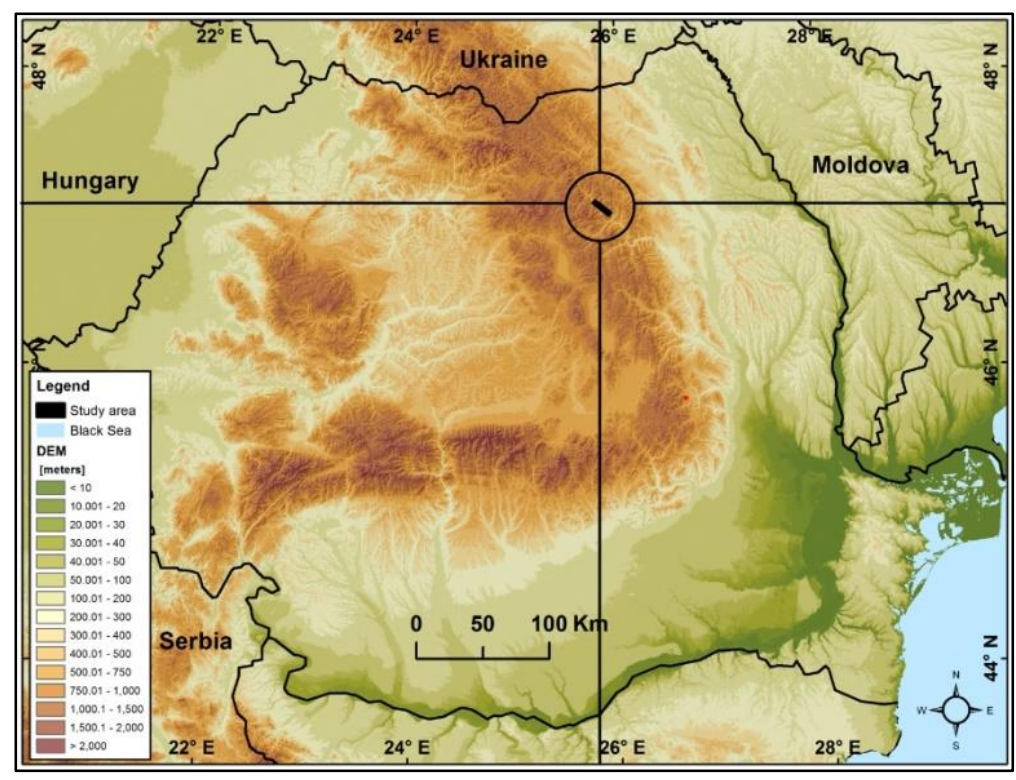

Figure 1. The localization of study area

\section{METHODOLOGY}

Throughout this study, we used the following software: ArcGIS 10.2, SAGA Gis, Global Mapper 17, R2V, Microsoft Office 365. The database needed for the creation of the study consists of the following raster and vector cartographic materials: topographic plans (1:5000), cadastral plans (OCPI Neamt), the digital elevation model of the ground (realized based on the 1:5000 topographic plans), Digital Terrain Model (DTM) obtained using LIDAR technology (with a $5 \mathrm{~m}$ DTM resolution), Orthophoto map 2012 in 1970 stereographic projection, floodplains $(0.1 \%, 1 \%, 5 \%)-\mathrm{ABA}$ Siret [33-42].

In order to highlight the areas with a slope favourable to the placement of houses, it was necessary to have a cartographic support which would serve as a basis for calculating the necessary parameters. The digital elevation model, obtained through the digitalization of the elements of relief from the 1:5000 topographic plains, represent the base of this study. The topographic plans were taken from OCPI Piatra Neamt,. The next phase consisted in the vector representation of all the categories of land usage, in order to identify the relative frequency of the land surfaces placed according to the current norms. The floodplains with three probabilities $(0.1 \%, 1 \%$, and $5 \%)$ were taken from ABA Siret and are used in order to highlight the territories affected by flooding risks. In order to map the areas favourable to construction according to the slope of the land, it was necessary to realize a map of the slopes, reclassified on four classes (class 1 - maximum favourability, class 2 restrictive favourability, classes 3 and 4 - totally unfavourable). The map of the fragmentation depth was realized in order to highlight the altitudinal steps and their layout in the territory. After identifying the maximum and minimum altitude on the same surface, it was possible to validate whether the area was favourable for construction in accordance with the calculated relief energy. An important phase of this study consisted in the overlapping of the floodplains with the thematic layers obtained. This phase was necessary for highlighting the areas that are favourable for construction from a geomorphological point of view, but with hydrologic restrictions caused by the flood risk susceptibility. 


\section{RESULTS AND DISCUSSIONS}

After the maps were created, the four classes of favorability on construction were delimitated. The analysis was realized in the extreme classes: 1 and 4 (favorable and unfavorable). The 1st class, with a slope of $0^{\circ}$ to $4.5^{\circ}$, represents maximum favorability for house placement, with no restrictions. It can be observed that the highest favorability is on the lower terraces of the meadows (with an altitude of 5 to $10 \mathrm{~m}$ from the minor river bed) and isolated, on the higher terraces. The 2nd and 3 rd classes, with a slope of $4.5^{\circ}$ to $13.5^{\circ}$, are mainly encountered on the terraces with a higher altitude and on the slopes. The $4^{\text {th }}$ class, with a slope higher than $13.5^{\circ}$, where house placement is impossible, occupies the largest surface in the area of study and it is dominated by forests, pastures, and grasslands.

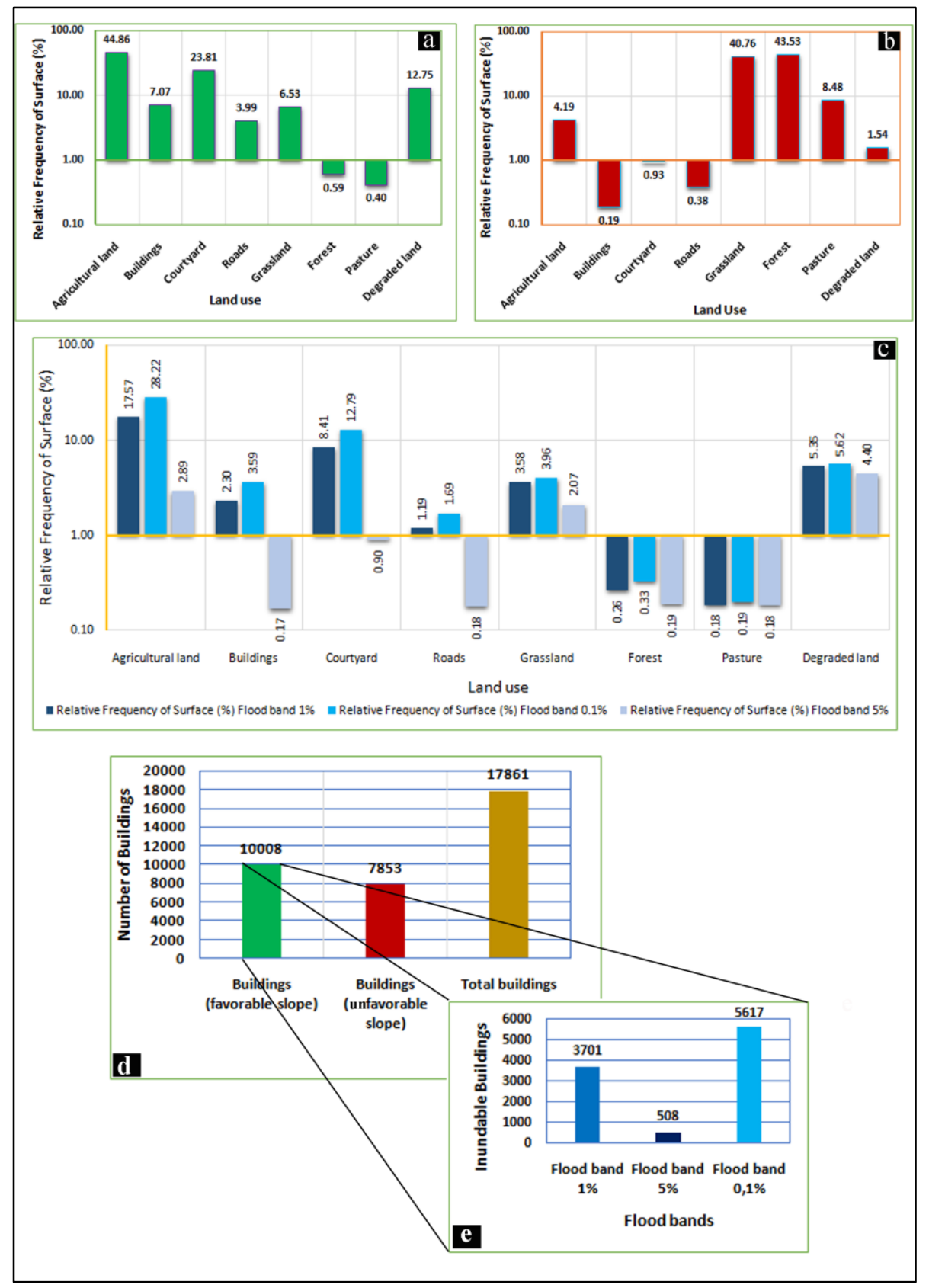

Figure 2. Land use and the relative frequency of flooded surfaces; a. Land use in an area with a favourable declivity; b. Land use in an area with an unfavourable declivity; c. Relative frequency of flooded surfaces in an area with favourable declivity; d. Buildings in an area with favourable slope, e. affected by flood

Figure $2 \mathrm{a}$ presented on the following page, highlights the usage of land in an area with a favourable declivity. This graph was obtained as a result of crossing two thermal layers: the vector polygons obtained from the reclassified map of the slopes and the land usage. This graph highlights the relative frequency of the categories of usage in the areas with a favourable slope. The percentage 
values represent the surface occupied by each category of usage in this area with reduced slope, favourable to house placement.

The arable land occupies the largest part of the surface $(44.86 \%)$, followed by yards and other related constructions. The degraded land is located mainly in the proximity of the minor riverbed of the Bistrița River, in areas with water erosion. Here, the declivity is at its lowest point, which is why the damaged land occupies a significant territory of the total surface with the favourable inclination $(12.75 \%)$. The smallest percentage of the surface is occupied by forests and pastures, their distribution being more common in an area with a higher slope, specific to the mountain area.

The distribution of the categories of usage suggests the unfavorability of housing placement in this area with high declivity, of more than $18^{\circ}(>30 \%)$ (Fig. $2 \mathrm{~b})$. Of the total surface with unfavourable slope, $0.19 \%$ is occupied by constructions. Due to the restricted space of the areas with low declivity, in this unfavourable zone, the arable land consists of only $4.19 \%$. Grasslands and forests are currently the main categories of land usage in this area.

The construction of houses in the area with a high slope requires high expenditures because an additional resistance structure must be created. Access paths are difficult to create, and because of this reason, there is a tendency for houses to be created in a more favourable declivity area, notably in the river beds and on the lower terraces.

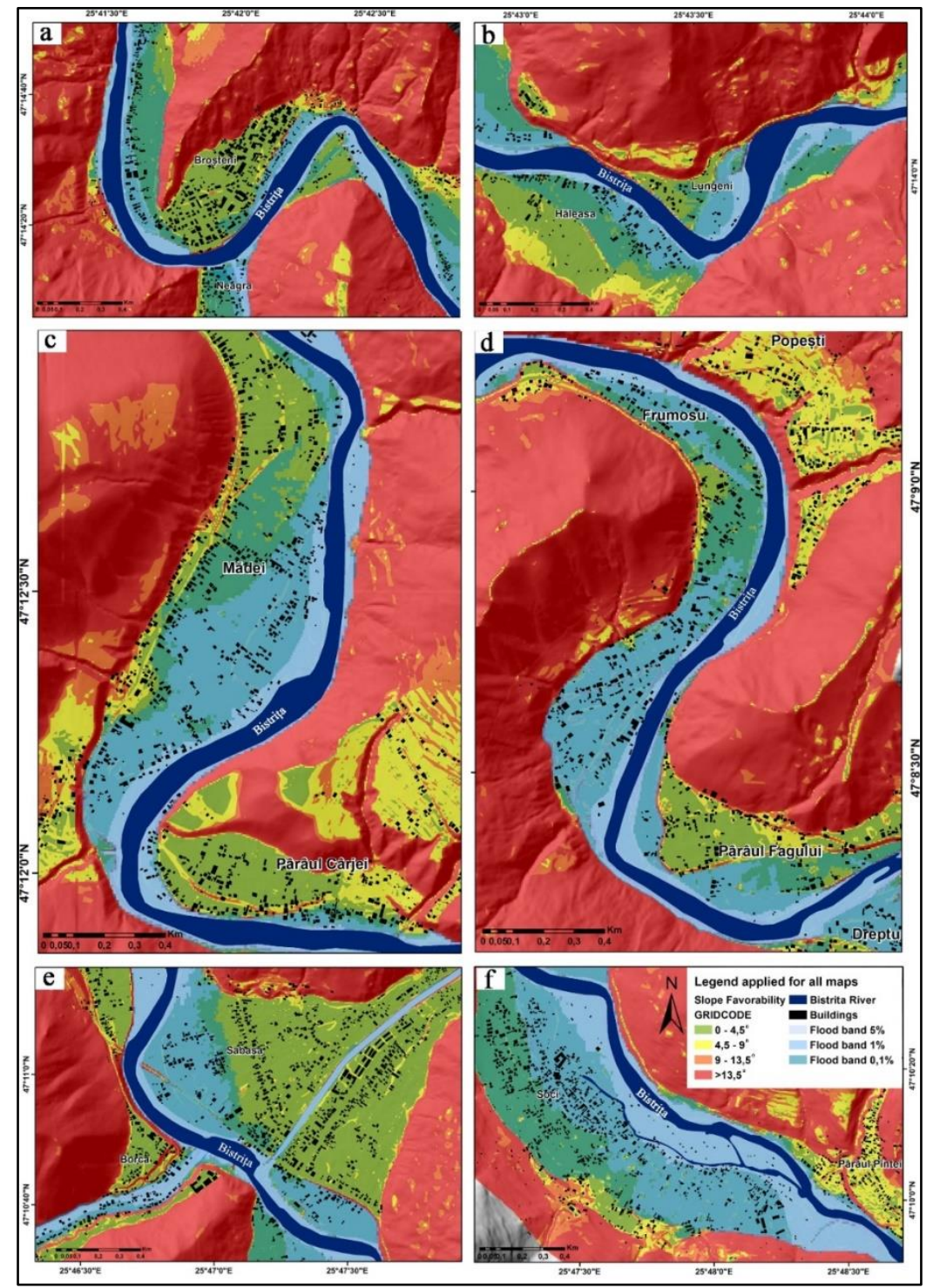

Figure 3. Cartographic representation of the favorability of building placement and of flood band with $0.1 \%, 1 \%$, and 5\% probabilities: a. Broșteni and Neagra; b. Hăleasa and Lungeni; c. Mădei and Pârâul Cârjei; d. Popești, Frumosu, and Pârâul Fagului; e. Borca and Sabasa; f. Soci

It has been demonstrated that although the meadow of the Bistrița river and its associated terraces have a slope that is favorable to house placement and agricultural activities, a large part of the area is 
susceptible to flooding, with different probabilities $(0.1 \%, 1 \%, 5 \%)$. By intersecting three thematic strata (the area with favorable declivity, the usage of land, and the floodplains) all the types of land usage susceptible to flooding are highlighted (Figure 2c). The arable land occupies the largest floodable surface in the sector with a slope lower than $4.5^{\circ}(17.57 \%$ in the case of the floodplains with a $1 \%$ probability, and $28.22 \%$ in the case of the floodplains with a probability lower than $0.1 \%$ ).

The total number of constructions from the whole study area is 17,861 (Figure 2d). Out of these, 10,008 are placed in an area with favorable slopes, and the other 7,853 are placed in areas with restrictions regarding the construction of houses (due to the high slopes). Of the 10,008 constructions placed in a favorable area from a geomorphological perspective, by crossing the floodplains with the $1 \%$ flooding probability, it was proven that 3,701 of them are at risk of flooding. (Fig. 2e). The $0.1 \%$ flooding probability can affect 5,617 constructions from the total of 10,008 placed correctly from a geomorphological point of view (favorable slope). The floodplains with a 5\% probability intersect 508 constructions.

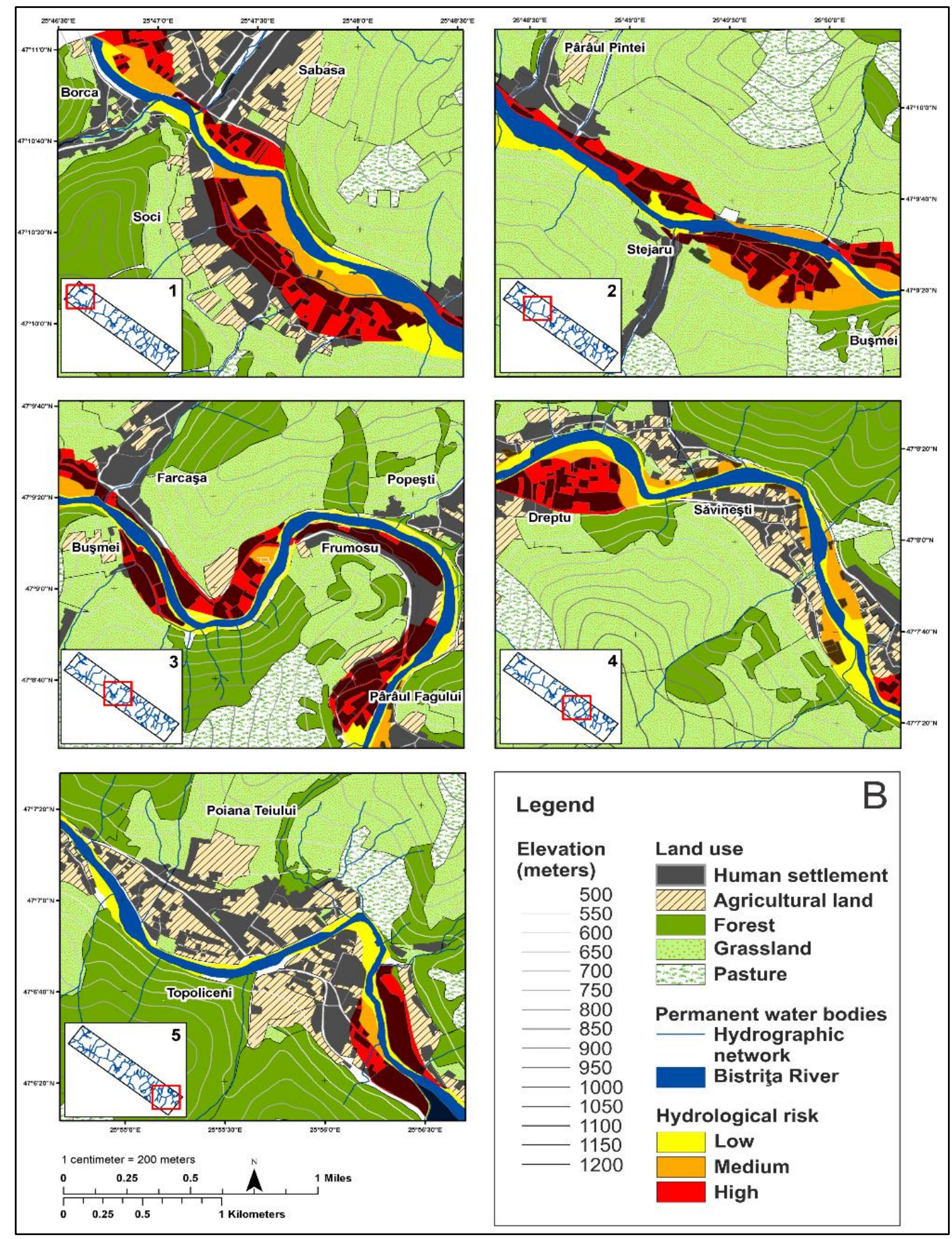

Figure 4. Flood risk maps within mountain sector of Bistrita River 
The overlapping of land usage and floodplains with the slope classes revealed the areas favorable to construction from a hydro-geomorphological perspective. The town of Broșteni is located in a favorable area because the declivity is low and the flooding risk is insignificant (Fig. 3a). The floodplain of $1 \%$ completely affects the lower meadow terrace $(2-3 \mathrm{~m})$ in Hăleasa, and the $0.1 \%$ spreads over the $5 \mathrm{~m}$ terrace, affecting most of the constructions (Fig. 3b). The slope favorability for construction is extended on a large surface, but the houses are placed in an area with a hydrologic risk. The $0.1 \%$ floodplain covers $75 \%$ of the village of Mădei, and the $1 \%$ floodplain covers $50 \%$ of it. This shows that most of the houses were placed wrongly, without taking into consideration the risk of flooding (Fig. 3c). In Pârâul Cârjei there is a flooding risk only on the $5 \mathrm{~m}$ terrace, the rest of the town being placed safely on the $10 \mathrm{~m}$ terrace. Popești is located on the $45 \mathrm{~m}$ terrace. From a declivity perspective, this village is placed in the second class of slope favorability $\left(4.5^{\circ}-9^{\circ}\right)$ but there are no chances of it being affected by flooding (Fig. 3d). On the other hand, the village of Frumosu is almost completely floodable, especially during winter, especially due to the freeze-thaw phenomena. The village of Sabasa is placed on an alluvial area, favorable to house placement in a proportion of $80 \%$ (Fig. 3e). The $1 \%$ and $0.1 \%$ floodplains enter the $5 \mathrm{~m}$ terrace surface and 63 constructions become susceptible to flooding, out of which 26 are houses. The most critical situation is in the Soci locality, in the Borca commune, located on a terrace with an altitude of $5 \mathrm{~m}$ (Fig. 3f). The whole village is placed on an area that is favorable from a geomorphological perspective (small declivity: between $0^{\circ}$ and $4.5^{\circ}$ ). But at the

\section{CONCLUSIONS}

After analyzing the cartographic materials and the related graphs it is noticed that in the proximity of the minor riverbed of the Bistrița River the following categories of land usage are predominant: yards, constructions, and arable land. The houses are located on the lower meadow terraces. The surfaces with reduced declivity favor their placement from a geomorphologic perspective, but at the same time, from a hydrologic perspective, they are susceptible to flooding. The surface that does not imply a hydro-geomorphological risk is very restricted. More than half of the total number same time, from a hydrologic perspective, the whole area with a favorable slope is susceptible to flooding on a $0.1 \%$ probability.

The $0^{\circ}-4.5^{\circ}$ slope class (which occupies $28 \%$ of the studied area) is almost continuous in the longitudinal profile of the river. It corresponds to the sector of meadows and lower terraces. The value range is between $4.5^{\circ}$ and $18^{\circ}$ and corresponds to the joining surfaces (slopes, terraces), to the upper terraces and the secondary interfluves (that were caused by erosion by the tributaries of the Bistrița River), all being inclined towards the valley. The areas with inclinations ranging between $18^{\circ}$ and $35^{\circ}$ occupy a significant surface in the Bistrița Valley, in the Broșteni Poiana Teiului sector. The greater share of these surfaces with high declivity is in the proximity of Borca (Bistriţa Mountains) and on the left slope, an almost all of its length. The high slope of the land favors the violent flow of Bistrița's tributaries, favoring strong floods.

We have opted for a qualitative risk assessment of the floods. Firstly, this involved the identification of risk receptors, and secondly the assessment of the vulnerability of the identified objects that are exposed to flooding, taking into account the depth of the water and the potential damage caused to the flooded objectives, as well as the impact on the considered risk receptors (Fig. 4). In this case, the water from abundant precipitation and transported in floods represents the hazard. The villagers, houses, and the land represent the vulnerable factor that generates the risk phenomena. The high risk degree is suggested by the large surface of yards and of constructions that are at risk of flooding with the probabilities of $0.1 \%, 1 \%$, and $5 \%$.

of houses are placed in an area with a risk potential. The mountain area from Bistriţa Valley does not permit the placement of houses on the slopes because of the large geo-declivity and of the difficulty of creating access paths. The optimal solution for preserving the current situation of the constructions is the appropriate damming of the Bistrița River and the improvement of river torrents (the river torrents causing floods more frequently than the main river). The best solution, excluding the current one, is to completely avoid the placement of houses in the proximity of the river.

\section{REFERENCES}

[1] Romanescu G. \& Nistor I. The effect of the July 2005 catastrophic inundations in the Siret River's Lower Watershed, Romania, Natural Hazards, vol. 57, no. 2, pp. 345-368, 2011.

[2] Radevski I., Gorin S., Dimitrovska O., Milevski I., Apostolovska-Toshevska B., Talevska M. \& Zlatanoski V. Estimation of maximum annual discharges by frequency analysis with four probability distributions in case of 
nonhomogeneous time series (Kazani karst spring in Republic of Macedonia), Acta Carsologica, vol. 45, no. 3, pp. 253-262, 2016.

[3] Mierla M., Romanescu G., Nichersu I. \& Grigoras I. Hydrological risk map for the Danube delta - a case study of floods within the fluvial delta, IEEE Journal of Selected Topics in Applied Earth Observations and Remote Sensing, vol. 8, pp 98-104, 2015.

[4] Romanescu G., Hapciuc O.E., Minea I. \& Iosub M. Flood vulnerability assessment in the mountain-plateau transition zone. Case study for Marginea village (Romania), Journal of Flood Risk Management, vol. 11, no. S1, pp. S502-S513, 2018.

[5] Romanescu G., Mihu-Pintilie A., Stoleriu C.C., Carboni D., Paveluc L.E. \& Cimpianu C.I. A Comparative Analysis of Exceptional Flood Events in the Context of Heavy Rains in the Summer of 2010: Siret Basin (NE Romania). Case Study, Water, vol. 10, no. 2, pp 216:1-17, 2018.

[6] Romanescu G., Cimpianu C.I., Mihu-Pintilie A. \& Stoleriu C.C. Historic flood events in NE Romania (post-1990), Journal of Maps, vol. 13, no. 2, pp. 787-798, 2017.

[7] Romanescu G., Jora I. \& Stoleriu C. The most important high floods in Vaslui river basin - causes and consequences, Carpathian Journal of Earth and Environmental Sciences, vol. 6, pp 119-132, 2011.

[8] Romanescu G., Stoleriu C. \& Romanescu A.M. Water reservoirs and the risk of accidental flood occurrence. Case study: Stanca-Costesti reservoir and the historical floods of the Prut river in the period July-August 2008, Hydrological Processes, vol. 25, no. 13, pp. 2056-2070, 2011.

[9] Romanescu G. \& Stoleriu C. Causes and Effects of the Catastrophic Flooding on the Siret River (Romania) in JulyAugust 2008. Natural Hazards, vol. 69, pp 1351-1367, 2013.

[10] Romanescu G., Cretu M.A., Sandu I.G., Paun E. \& Sandu I. Chemism of Streams Within the Siret and Prut Drainage Basins: Water Resources and Management, Rev. Chim. (Bucharest), vol. 64, no. 12, pp. 1416-1421, 2013.

[11] Romanescu G., Tarnovan A., Sandu I.G., Cojoc G.M., Dascalita D. \& Sandu I. The Quality of Surface Waters in the Suha Hydrographic Basin (Oriental Carpathian Mountains), Rev. Chim. (Bucharest), vol. 65, no. 10, pp. 1168-1171, 2014.

[12] Romanescu G., Cojoc G.M., Sandu I.G., Tirnovan A., Dascalita D. \& Sandu I. Pollution Sources and Water Quality in the Bistrita Catchment (Eastern Carpathians), Rev. Chim. (Bucharest), vol. 66, no. 6, pp. 855-863, 2015.

[13] Cojoc G., Romanescu G. \& Tirnovan A. Exceptional floods on a developed river. Case study for the Bistrita River from the Eastern Carpathians (Romania), Natural Hazards, vol. 77, no. 3, pp. 1421-1451, 2015.

[14] Romanescu G., Iosub M., Sandu I., Minea I., Enea A., Dascalita D. \& Hapciuc O.E. Spatio-temporal Analysis of the Water Quality of the Ozana River, Rev. Chim. (Bucharest), vol. 67, pp 42-47, 2016.

[15] Romanescu G., Hapciuc O.E., Sandu I., Minea I., Dascalita D. \& Iosub M. Quality indicators for Suceava river, Rev. Chim. (Bucharest), vol. 67, 2, pp. 245-249, 2016.

[16] Hapciuc O.E., Romanescu G., Minea I., Iosub M., Enea A. \& Sandu I. Flood susceptibility analysis of the cultural heritage in the Sucevita catchment (Romania), International Journal of Conservation Science, vol. 7, no. 2, pp. 501510, 2016.

[17] Romanescu G., Tirnovan A., Cojoc G.M. \& Sandu I.G. Temporal variability of minimum liquid discharge in Suha basin. Secure water resources and preservation possibilities, International Journal of Conservation Science, vol. 7 , no. 4, pp. 1135-1144, 2016.

[18] Romanescu G. \& Stoleriu C. Exceptional floods in the Prut basin, Romania, in the context of heavy rains in the summer of 2010. Natural Hazards and Earth System Sciences, vol. 17, pp. 381-396, 2017.

[19] Enea A., Hapciuc O.E., Iosub M., Minea I. \& Romanescu G. Water quality assessment in three mountainous watersheds from eastern Romania (Suceava, Ozana and Tazlău rivers), Environmental Engineering and Management Journal, vol. 16, no. 3, pp. 605-614, 2017.

[20] Testa B., Aldighieri B., D’Alberto L., Lucianetti G. \& Mazza R. Hydrogeology and Hydromorphology: a Proposal for a Dual-Key Approach to Assess the Geo-Hydrological Heritage Site of the San Lucano Valley (Belluno Dolomites, Italy), Geoheritage, pp. 1-20, 2018. https://doi.org/10.1007/s12371-018-0279-y

[21] Tošić R., Lovrić N. Dragićević S. \& Manojlović S. Assessment of torrential flood susceptibility using GIS matrix method: case study - VRBAS river basin (B\&H), Carpathian Journal of Earth and Environmental Sciences, vol. 13, no. 2, pp. 369-382, 2018.

[22] Vasileski D. \& Radevski I. Analysis of high waters on the Kriva Reka river, Acta Geographica Slovenica, Macedonia, pp. 363-377, 2015.

[23] Yang H.C., Wang C.Y. \& Yang J.X. Applying image recording and identification for measuring water stages to present flood hazards, Natural Hazards, pp. 737-754, 2014.

[24] Zeleňáková M. \& Fijko R.\& Diaconu D.V. \& Remeňáková I. Environmental Impact of Small Hydro Power Plant-A Case Study, Environments, vol. 5, pp. 12, 2018. 
[25] Serban G., Rus I., Vele D., Bretcan P., Alexe M. \& Petrea D. Flood-prone area delimitation using UAV technology, in the areas hard-to-reach for classic aircrofts: case study in teh north-east of Apuseni Mountains, Transylvania, Natural Hazards, vol. 82, no. 3, pp. 1817-1832, 2016.

[26] Tokar A., Negoitescu A., Hamat C. \& Rosu S. The Chemical and Ecological State Evaluation of a Storage Lake, Rev.Chim. (Bucharest), vol. 67, no. 9, pp. 1860-1863, 2016.

[27] Chen Z.M., Yeh Y.L. \& Chen T.C. Assessment of a Regional Flood Disaster Indicator via an Entropy Weighting Method, Natural Hazards Review, vol. 19, no. 2, 2018. https://doi.org/10.1061/(ASCE)NH.1527-6996.0000280

[28] Radevski I. \& Gorin S. Floodplain analysis for different return periods of river Vardar in Tikvesh valley (Republic of Macedonia), Carpathian Journal of Earth and Environmental Sciences, vol. 12, pp. 179-187, 2017.

[29] Reti K.O., Malos C.V. \& Manciula I.D. Hydrological risk study in the Damuc village, the Neamt county, Journal of Environmental Protection and Ecology, vol. 15, pp. 142-148, 2014.

[30] Nicu I.C. \& Romanescu G. Effect of natural risk factors upon the evolution of Chalcolithic human settlements in Northeastern Romania (Valea Oii watershed). From ancient times dynamics to nowadays degradation, Zeitschrift für Geomorphologie, vol. 60, pp. 1-9, 2016.

[31] Romanescu G. \& Stoleriu C. Anthropogenic interventions and hydrological-risk phenomena in the fluvial-maritime delta of the Danube (Romania), Ocean \& Coastal Management, vol. 102, pp. 123-130, 2014.

[32] Cozma D.G., Cruceanu A., Cojoc G.M., Muntele I. \& Mihu-Pintilie A. The factorial analysis of physico-chemical indicators in Bistrita's upper hydrographical basin, SGEM2015 Conference Proceedings, Geoconference on Water Resources, Forest, Marine and Ocean Ecosystems, Bulgaria, vol. 1, pp. 625-632, 2015. Doi: 10.5593/SGEM2015/B31/S12.080

[33] Cruceanu A., Cojoc G.M., Cozma D.G., Muntele I. \& Mihu-Pintilie A. Comparativ study of surface waters quality in the hidrographic upper basin of Bistrita River (Romania), SGEM2015 Conference Proceedings, Geoconference on Water Resources, Forest, Marine and Ocean Ecosystems, Bulgaria, vol. 1, pp. 159-166, 2015. Doi: 10.5593/SGEM2015/B31/S12.021

[34] Mihu-Pintilie A., Asandulesei A., Nicu I.C., Stoleriu C.C. \& Romanescu G. Using GPR for assessing the volume of sediments from the largest natural dam lake of the Eastern Carpathians: Cuejdel Lake, Romania, Environmental Earth Sciences, vol. 75, no. 710, 2016. Doi: 10.1007/s12665-016-5537-1

[35] Donisa I. Geomorfologia Vaii Bistritei, Editura Academiei Republicii Socialiste Romania, Bucuresti, 1968.

[36] Romanescu G., Cotiuga V., Asandulesei A. \& Stoleriu C. Use of the 3-D scanner in mapping and monitoring the dynamic degradation of soils. Case study of the Cucuteni-Baiceni Gully on the Moldavian Plateau (Romania), Hydrology and Earth System Sciences, vol. 16, pp. 953-966, 2012.

[37] Romanescu G. Alluvial Transport Processes and the Impact of Anthropogenic Intervention on the Romanian Littoral of the Danube delta, Ocean \& Coastal Management, vol. 73, pp. 31-43, 2013.

[38] Romanescu G. \& Stoleriu C. An inter-basin backwater overflow (the Buhai Brook and the Ezer reservoir on the Jijia River, Romania), Hydrological Processes, vol. 28, no. 7, pp. 3118-3131, 2013.

[39] Romanescu G. \& Nicu C. Risk maps for gully erosion processes affecting archaeological sites in Moldavia, Romania, Zeitschrift für Geomorphologie, vol. 58, no. 4, pp. 509-523, 2014.

[40] Romanescu G., Chalov S., Stoleriu C.C., Mihu-Pintilie A., Angileri S.E., Kuznetsova Y., Cama M. \& Maerker M. Geomorphologic map of the $1^{\text {st }}$ Mutnaya River, Southeastern Kamchatka, Russia, Journal of Mountain Science, vol. 14, no. 2, pp. 2373-2390, 2017.

[41] Diaconu D.C., Andronache I., Ahammer H., Ciobotaru A.M., Zelenakova M., Dinescu R., Pozdnyakov A.V. \& Chupikova S.A. Fractal drainage model - a new approach to determinate the complexity of watershed, Acta Montanistica Slovaca, vol. 22, pp 12-21, 2017.

[42] Castillo C. \& Gómez J.A. A century of gully erosion research: Urgency, complexity and study approaches, EarthScience Reviews, vol. 160, pp 300-319, 2016. 